Island Studies Journal, Vol. 5, No. 2, 2010, pp. 141-164

\title{
Saltwater Chronicles: Reading Representational Spaces in Selected Book Clubs in St. John's, Newfoundland
}

\author{
Judith P. Robertson \\ University of Ottawa, Canada \\ jrobert@uottawa.ca \\ David Lewkowich \\ Doctoral Candidate, McGill University, Canada \\ dlewkowich@yahoo.ca
}

and

Jennifer Rottmann

Doctoral Candidate, University of Ottawa, Canada

jennrotty@yahoo.ca

\begin{abstract}
Saltwater Chronicles investigates the notion of "islandness" in contemporary Newfoundland readership through two in-depth case studies of book clubs as representational spaces in the elaboration of local knowledge and identities. We demonstrate how select Newfoundland readers perform acts of regeneration in which the lived, loved, and experiential dimensions of literary space come to invoke the permeability of psychic and geographic borders, the dangers and possibilities of the landwash, and the always-already precarious designation of limits between self and other. We provide examples of how, for these island readers, "islandness" as a symbolic point of address slips and border-crosses in the in-between semiotic spaces of literary encounter.
\end{abstract}

Keywords: islandness, book culture, literacy studies, Newfoundland, borders, landwash

(C) 2010: Institute of Island Studies, University of Prince Edward Island, Canada

\section{Introduction}

In his desire to write a "real world literary criticism" where place is read alongside literature in order to imbue reading experience with cultural meaning, Ian Marshall conjures "an ecology of reading," in which "life, literature, and theory interconnect and merge in a meaningful way, everything hitched to everything else" (1998: 71, 8). Marshall, a professor-cum-literary pilgrim, strikes out in solitude through the Appalachian Trail, filling the element with literary heroes and the echo soundings of local readers. By drawing wide the circle of "literature and land" (ibid.: 102), his signatures lend exteriority and intimacy to his private readings. His presence on a map of geographical spaces invites him to come out of himself, and he realizes that "place matters as much as plot" (ibid.: 66) in literary theory. Marshall reflects on how boundaries entangle and blur in the reading process. His use of geography and space as vectors of meaning in his cultural study of the 
everyday demonstrates, not only how knowledge and lives are organized and maintained in highly localized ways that extend sedimentary knowledge, but how research that expresses the fluidity of these operations under the conditions of their interconnectedness can challenge the way reading is characterized.

Like Marshall, we undertake here a "real world literary criticism" of how particular book cultures take root (and routes) out of the landwash - where water, as a fundamental and life-sustaining force, both nourishes human life as its drift simultaneously produces disorientation and catastrophe - of everyday psycho-geographical spaces in reading. We draw on a wide range of interdisciplinary theories to write literary space into the geography of islands: both as material and physical spaces, and as metaphoric, mythic, and psychic spaces. Based on a qualitative study conducted between 2003 and 2007 by a research team of three, we examine group reading experience through the phenomenon of two adult book clubs in St. John's, Newfoundland.

Taking our start-up cue from book historian and cultural theorist Robert Darnton (1982), we examine what readers make of books in particular lived instances. We ask how the study of book use in situ can augment the extraordinarily complex history of literary knowledge, especially by attending to the complexities that shape literary experience within marginal settings. In order to keep true to the question of book history in relation to geography, we also call on cultural theorist Henri Lefebvre, who proposes the concept of representational space (1991: 24). The idea refers to the experiential, chaotic, and subjectively articulated spaces of everyday reading practices, as opposed to representations of space-professional representations that create official (often hegemonic) versions of literary experience that may not imbue readers with agency, struggle and aliveness. For Lefebvre, space is a key constituent of cultural life, mobile and dynamic, something that makes itself felt to a great number of people at the same time: directly lived, ephemeral, and appropriated through actual sensory experience (1991: 413). For Deleuze and Guattari (1987: 11), the book provides a consummate instance of deterritorialization and reterritorialization within representational spaces. The book forms a "rhizome" with the world, a piece in the dynamic movement of culture, weather, and geography, transforming author intentionalities by taking on the modifications, psychic valences and performances of readings, "a broken chair of affects and variable speeds, with accelerations and transformations" (Deleuze \& Guattari, 1987: 8). For Homi Bhabha (1996), margins are good spaces for studying these intricate processes, "third spaces" that challenge and resist dominant culture.

Our study of reading experience unfolds within the port city of St. John's, Newfoundland. To help us bring into sharper juxtaposition the rhythms of urban readers within this island jurisdiction, we draw inspiration from the work of Harry Hiller (1999), Anne Buttimer (2008), Paul Chafe (2008), and Walter Benjamin (1997). Each of these theorists draws unique attention to the cultural particularities of what - in Newfoundland - is referred to as "the townie". For example, Hiller studies embourgeoisement within Canadian inner cities, observing how class transformations from servitude to sufficiency give rise to haunted memories in the metropolis - in kitchens, pubs, and attics where people gather. For Buttimer, the distinctive geographies of such space/place rhythms can only be accessed through the study of embodied landscapes. Spaces become places through communal practices of the vernacular-like eating, building, or reading - through which embodied 
habits (like gender or profession) get over-written and re-signified (Sanders, 1997; Mels, 2004). Paul Chafe catapults us squarely into the literary scene in Newfoundland to reveal how, at least in the view of Newfoundland writer Michael Winters, the dwellers of St. John's use their city experience "... to formulate ... fragmented visions of themselves" (2000: 9). For Winters, "the townies" look to rural Newfoundland ("the baymen") "to know that their identities as Newfoundlanders are somehow anchored there, possibly inaccessible to them as modern city dwellers" (ibid.). These accounts of the haunted nature of reading and identity on the streets take us finally to Walter Benjamin's notion of the Flanêur, the bourgeois observer and roving formulator of ideas for whom the street is simultaneously a dwelling place and an unheimlich, or "unhomely", space (Other Voices, 1997).

Later in this paper we spiral back to this commonwealth of images, having to do with margins, memory, and migrations in reading. For now, we ask how the location of two book clubs perched on the border of a border may be seen to contribute not only to a collective sense of being and meaning within, but the social, intellectual, political, and cultural work and play that urban islanders do together. Book clubs enter the spotlight here as unexamined representational spaces, whose psycho-geographical cadences have long inhabited what Elizabeth Long calls a "zone of cultural invisibility" (Long, 2003: 8). If, as Long argues, "social isolation depresses readership, and social involvement encourages it" (ibid.), then it is important to know how such gestures play out in specific instances (see also Nafisi, 2003; Laity, 2001; Radway, 1997; Kaufman, 2004). In her study of Canadian book clubs, Danielle Fuller advocates an "attention to the particular and [an] avoidance of the generalizing claims that can so easily obliterate difference and specificity" where "knowledge is lost, not gained" (Fuller, 2004: 11). Bearing in mind these cautionary notes, we take a moment to reflect on what led us to Newfoundland.

\section{Why Newfoundland?}

Our chosen research destination was the archipelagic island of Newfoundland. By archipelagic, we invoke not only the geographic and topological character of the North Atlantic islands that served as the site of our Saltwater Chronicles, but more importantly, our conceptual commitment to a transgression of boundaries. When "islandness" gets marked by the trope of "archipelagic", the island's determining status as essentially one of inter-relatedness is underscored (Schwyzer \& Mealor, 2004). Our position as researchers from Mainland Canada made us - like Ian Marshall - literary pilgrims of sorts, committed to leaving the pages of literary works studied in easy isolation to travel to less wieldy scenes of their appropriation. Islands "are crossroads [and] markets for exchange." They “... are also enclosures within which intimate ecological relations prevail" (Beer, 2003: 35). While the "islandness" of archipelagic spaces can make them function as a looking glass for both insiders and outsiders in the projection of fears or idealizations, Newfoundlanders have had good reason for exercising wariness toward mainlander representations. For five hundred years, the island was carved up among Europeans who vied for its riches along $10,000 \mathrm{~km}(6,250$ miles) of coastline teeming with cod (Walsh \& Jones, 2007). Newfoundland writers often characterize the province's history in terms of destitution and loss: Beaumont Hamel, bankruptcy, Confederation, Resettlement, Churchill Falls, the Ocean Ranger, the closure of the cod fishery, the migration of Newfoundlanders 
to Fort McMurray: "A sense of betrayal and broken dreams hangs over this place like fog," says Lisa Moore in Hard Rock and Water (Doran, 2005). A "grand narrative of struggle" characterizes Newfoundland identity, a "psychic wound" with a "nagging notion of failure at the core" (Bannister, 2003: 128, 132).

Despite our awareness that these mythic tropes of loss, betrayal, and endurance circulate as unstable linguistic markers to construct insider notions of Newfoundland identity, we also understood the extent to which such slippery images have been deployed in a limiting manner by the Newfoundland tourist industry to construct - for the purposes of commodification and profit - an image of "Real Newfoundland." For Jim Overton, the result has been calamitous for island inhabitants. For the unthinking outside/tourist interested only in the romantic and picturesque, Newfoundland gets conflated with something primitive or uncivilized (Overton, 1980: 115). And for the insider, the figures may also unwittingly invade desire, leading Paul Chafe to observe that a sense of "perpetual belatedness" permeates Newfoundland self-representation: a notion that Newfoundlanders arrive too late to prevent losses that they are nevertheless defined by and driven to recoup or replace (2008: 26).

Accordingly, if we were to seize book club space here in "its specific reality", as Bachelard entreats in Poetics of Space (1964: xix), then this network of historical and geographical factors would need to configure. This would demand being both recursive and reflexive as researchers, remaining attentive to both the dangers of fetishization, and the real relations of dominance in which, as academics from Mainland Canada, we were implicated. As one book club respondent warned: "There is a strong sense of place here and a defensiveness about the preconceived notions the rest of the country may have about Newfoundland, or any 'high fulluting mumbo jumbo"'.

The position we took is that Newfoundland readers as a group tend to identify with each other and with the homeland as "insiders", and perhaps even more so in the Newfoundland diaspora (Delisle, 2008). These dynamics held important implications for what might be possible for us to learn as researchers. Within our psychic imaginary, the material/metaphorical categories of insularity, marked by categories of "insider" and "outsider" did exist, and Harold Horwood's condemnation of "upalongs" as "parochial", possessing "little interest in Canada's coast regions" (2000: 206) had a chastening effect. Newfoundlanders have long self-identified as occupants of liminal space: "partway between the Old World and the New, partway between being a country and a province ...torn between its storied past (which is both a burden and blessing) and the allure of the future; we love the word Newfie/we hate the word Newfie; the people here are border dwellers-lodged between the earth and the sea" (Callanan, 2007: 4). The "impossibility of isolating the Newfoundland essence" (and yet the curious compulsion to do so) haunts the shifting ledgers of Newfoundland literature (Chafe, 2007: 40). We set out to evoke the non-determinate gap between the island as material/physical space and the island as metaphor/mythic/psychic space for our readers. In so doing, we drew poetic inspiration from Tidalectics (Braithwaite, 1983: 9-53; also DeLoughrey, 2000, 2007), in which evocative images prevail that foreground the island as topos, an unceasingly active space of exchange between land and sea, perceptible in discourse. And so it was that we landed on the island, intent on hearing something of both the history and identity of the place, 
discernible through the exchanges bespoken within two communities of book club readers themselves.

\section{A Brief Look at Book Clubs in Newfoundland}

While literary clubs have existed since medieval times (Manguel, 1998: 250), it wasn't until the late 1700s that their widespread popularity moved into major urban centres throughout Europe and America, including Newfoundland. Mass produced, mass marketed, and mechanically produced popular and affordable goods (including books), while certainly not the defining element of daily life in St. John's in the early 1800s, nevertheless gave rise there to a new and unprecedented scribal culture of print. In turn, the effects of this new scribal culture arguably enabled the "imagined community" of Newfoundlanders to begin to constitute themselves symbolically through the effects of popular discourse (Anderson, 1983). Historians of the book in Newfoundland identify three factors that hastened the flow of books into settler's lives: permanent settlement on the island (after 1800), the defeat of Napoleon in 1815, and a thriving trade of fish and seal products with the Caribbean and the West Country of England contributing to a growth in prosperity (Barker \& Hannaford, 2009; Devereux, 1963). With a year-round population at about 40,000, the first printing house and newspaper were approved for start up as the King's Printer in 1807, followed by the establishment of the St. John's Library Society (1827), a circulating library (1846), and a Reading Room (1849) (Devereux, 1963: 58). Newspapers secured for the reading public at that time (comprised primarily of a white, male professional elite) arrived from Scotland, Ireland, England and the United States, including dailies (often a tad late off the boat) from New York, Edinburgh, Exeter, Plymouth, Glasgow, and Boston (ibid.: 60).

But by far the most robust historical precursor to modern day book club activity in St. John's was the Atheneum Club, set up in 1861 and, until its demise in 1898 modelled intellectually and philanthropically after parent groups in Liverpool (established in 1797), Boston (1807), London (1824), Halifax and Toronto (1843). Dedicated to the "cultivation and diffusion of knowledge" via a library, a reading room, and popular lecture and music series, the Atheneum Club reached out for "non sectarian support" from "every liberal minded and public spirited citizen" (Morris, n.d.) The Atheneum Library boasted a collection of 6,000 books, and its handsome building on Duckworth Street (destroyed by fire in 1892) housed an auditorium capable of holding 1,000 people. Just how far this liberal institution went in diminishing the suffering — or at least the interminable winters and late springs - endured by the citizens of St. John's at the time might be gleaned through its line-up of fashionable lectures, focussed on topics such as "British Poetesses" (1871), "Darwinism" (1873), "Fragmentary Literary Lives" (1873), "The Sea" (1875), "The Anatomy of Cheerfulness" (1878), and "Electric and Other Lights" (repeated by popular demand, 1878). When attendance plummeted in the late 1880s, "weather" was ranked as a leading offender, alongside "the cheapness of literature by American reprints," and young men's preference of "the Clubs" where smoking was permitted (Morris, n.d.: 36-38).

Notwithstanding the Atheneum Club of St. John's, George Story once said that the history of the book in Newfoundland would constitute a "very slim volume" (Barker \& Hannaford, 2009: paragraph 8): 
Much of the history of the book proceeded through individual or small group interventions, not as part of a broad general culture. Up to this century, most people could not read and even of the ones who did, many were not caught up in a bookish culture. Life was very tough for most inhabitants here, and reading was a luxury. ...Also...what looks like a history of the book in Newfoundland may become, if one is not careful, a history of the book in St. John's (ibid.: paragraph 61).

Despite these admonitions, we felt there to be aspects of book club culture in St. John's deserving of study.

\section{Narrowing the Scope: Finding the Clubs and Engaging the Readers}

The original aim of our research was to examine the circumstances of a single book club running out of a bookstore in St. John's, known in 2002 as the Saltwater Chronicles Bookstore. Of particular interest was the unusual dedication of these readers to the exclusive reading of Newfoundland literature. When we arrived in St. John's in the summer of 2003 to commence the study, we were distressed to learn that the bookstore had gone out of business, and the book club disbanded. Through a letter to the editor subsequently placed in the St. John's Telegram and appearing in 10 regional newspapers throughout Newfoundland and Labrador in the fall of 2003, we invited book clubs throughout the province, especially those in rural areas, to contact us for possible inclusion in the study. Within the next twelve months, we sustained a hearty email correspondence with enthusiastic members (mostly women) of some 20 book clubs, vastly spread throughout the coastal and interior regions of NL in such communities as Harbour Grace, Grand Falls, Happy Valley/Goose Bay, L'Anse Au Loup, Gander, Eastport, Roddickton, Corner Brook, and St. John's. Some important themes of the research came out of this rich but informal, preliminary period of the study. One particularly elaborate set of discourses emerged from a robust series of emails from a St. John's woman (a former librarian), whose passion for reading in two book clubs furnished pages of brisk first-hand accounts of group politics, interplay, and insider leads.

This early phase of the study furnished important evidence not only that book culture thrived throughout Newfoundland and Labrador, but that it functioned to produce forms of sociality, escape, identification, philanthropy, and intellectual passion in readers. We learned that community outreach (in the form of student bursaries, fund raising, and book fairs) was a common practice. Meetings followed common rituals, including a calendar of readings, book selection protocols, speaking rituals, and electronic book procurement strategies. More surprisingly, we learned that all the clubs in our preliminary study read prize-winning literary selections penned primarily by non-Newfoundlanders. When we queried this practice, one response was:

The attitude toward Newfoundland literature has been slow (maybe resistant) to change here. Local authors are often only read when they receive outside recognition. It's that very Canadian thing of when you make it big elsewhere, Canadians are there to say, 'Welcome Home'. 
The pattern of island book club readers reading primarily non-island authors struck us as a practice in need of our further unravelling. It certainly introduced us to the notion of a contemporary Newfoundland readership unfrozen in literary time, specializing in cosmopolitan reading experience, active, arduous, and anything but driven by the "panicked nostalgia" that presents Newfoundland identity as single or distinct in its ethos or character (Overton, 1988).

Notwithstanding, this early direction of the research came to a halt when the real physical and theoretical challenges of travelling from Mainland Canada to participate and observe within local sites spread from central Labrador to three coasts and interior communities of Newfoundland, including St. John's, became obvious. In 2005, we made the difficult decision to narrow the scope of the study. Using connections already established in St. John's, the team decided to focus the research on urban island readers in two book clubs. We then spent extended periods of time living in St. John's, working on the ground with ideas, readers, and the rich vocabularies of place emanating out of lived book club experience. In preparation for fieldwork throughout 2006 and 2007, we read deeply in the literary and cultural theories identified above, meeting regularly to exchange ideas. We used multiple methods informed by cultural studies, autoethnography (Ellis, 2004), and anthropological poetics (Brady, 2000) over a three year period to collect data by interviewing participants (face to face and online), attending club meetings, transcribing and analyzing club documentation, reading club literary selections, keeping diaries, making a film documentary, and examining texts written by club members. These pathways allowed us to experience first hand how the book clubs organized and defined themselves, how they set goals and produced readers that could function within their conditions, and how reading subjects were produced through such complex spatialities. Here below, presented case by case, are our commentaries on the research. The case studies lead to preliminary discussions and concluding remarks, which return us to the central question of readership and island studies, and the significance of complex symbolic appropriations within the shifting tidalectics of literary space in St. John's, Newfoundland.

\section{Poaching in the Landwash: Case Study \#1}

Our first case study examines a "book club" self-identified as the Humanities, Arts and Medicine Interest Group, or HAM. The title is an acronym and simultaneously references the jocular tendencies of Dr. Seuss (Green Eggs and Ham), the corporeal pleasures of consumption, and an overall tendency in the group's discussions towards 'hamming it up.' $H A M$ is easy to remember and reflective of the group's range of interests, also pointing to light heartedness and an imperative, as one reader states, "not to take yourself too seriously." $H A M$ also signifies an important aspect of group identity within the readers, which is about border crossing: "It's... about seeing different sides to things," and as one reader continues, "there's something about the spirit of curiosity and inquiry that...goes very well with the spirit of humour." Organized out of Memorial University's Faculty of Medicine and meeting monthly at an on-campus pub called Bitters, the members of this reading group (they eschew the title of "book club") share an interest in how the practice of medicine is represented and conceptualized in literature, music, television, film, and the arts in general. 
Urban St. John's is a small but lively and intimate cultural venue, often attracting individuals of a creative ilk interested in the various modes of cultural production ranging from the literary and theoretical to the scientific. In the words of Scott Russell Sanders (2006: 4), it is a "real place... a cherished place". People choose "not merely to live there, but to photograph and paint it, to write it and sing of it...archaeologists and historians delve into its past...naturalists keep track of the local flora and fauna; and...elders pass all this lore to the young" (ibid.). The book club we studied includes five readers who live and labour here as both students and faculty members from a variety of university disciplines, including history, literature, medicine, and arts. As a space for engaging the disruptive uses that literature brings to medicine, HAM is marked simultaneously by marginality within the university setting, economic privilege (relative to island inhabitants in general), cultural capital (Bourdieu, 1984), and wide flung cultural influence. The group sees the arts and medicine as complementary fields insufficient unto themselves. Given the high public profiles and status enjoyed by many of its members, and in the interests of protecting, to the best of our ability, their voices and anonymity, we here introduce them with scant biographical or professional information other than their pseudonyms: Karen (the group's instigator), Alan, Dara, Cathy, and Gail.

While working with this group, we engage with their reading experiences of two books. The first, Paula, by Isabel Allende (1996), can be described simultaneously as an act of mourning, a confessional, a journal, and an autobiographical work of magical realism. The second, Quick, is a collection of poetry by Anne Simpson (2007), whose principal themes are death, the body, the natural world, transubstantiation, and the ways in which thresholds and borders manifest themselves in everyday life. We focus on how HAM readers interact with this material to constitute themselves subjectively in discursive practice, and how they use each other to negotiate the porous boundaries between medicine and humanities. Within the larger guiding ethos of the Saltwater Chronicles Research Project, we ask how $H A M$ members use social reading to construct a praxis for negotiating the medical humanities; how urban/island geography impacts on how books are read; and how the 'inbetweenness' of readers (who are both native and non-native islanders positioned in the inter-disciplines of Medicine and the Humanities) relate to reading in a landwash site. Our analysis attends to the ways in which HAM's readers actually deploy the language of communal reading experience to situate themselves discursively as readers in the landwash $A N D$ as island dwellers in the urban. We identify four hybrid positionings through which our research participant's subjectivities play out.

\section{a) Reading as Fracturing Boundaries}

In book discussions, HAM's readers tread to the edges of disciplines and ideas, where sight-lines and boundaries end. Cathy states that HAM is "helping expand my horizons." There's "a way of spreading out in our discussion about things, and just sharing our knowledge at a very humanistic level." Alan echoes, "I'm reading things that I would probably never have read, and I'm introduced to different sources that I was unaware of... so I'm finding new territories I didn't know. So that's one of my pleasures." Dara also acknowledges the pleasures of opening out by reading through $H A M$ and finding herself in domains that "I would not have discovered on my own." 
The group takes great pride in distancing itself from orthodoxy, and repeatedly defines its aspirations as being set apart from rigid institutional standards. It refuses to make rules or partake of procedures that typically govern book club culture (Fowler, 2004; Huntley. 2003; Radway, 1997; Shaffer \& Barrows, 2009). Meeting in a pub, refusing to name themselves as a "book club", and balking at the idea of moderating discussions or setting protocols around how a book will get discussed, are all examples of how $H A M$ 's readers use representational space to fly under the radar screen of official discourses and boundaries. Discussions are governed by the mutable and momentary desires of the readers, who are sometimes searching for support and camaraderie, while at other times simply enjoying an immersion in the interruption that the group provides. "What happens, happens", says Alan. In his description of the group's techniques for book selection, he describes it as a capricious affair, with "[a]bsolutely no method, and mostly madness". As a space that encourages relations in reading that are "completely serendipitous," Alan also sees in HAM not only chance, but in "the very fact that I know I may have to bare my soul a bit", a chance for something significant to emerge in the passing moments of the group's discussion.

There is both risk and pleasure in this aspect of HAM's functioning. As Karen puts it, "At first I thought, 'Ewww. No, I'm not into clubs and stuff'. But then I thought, 'Well, who knows, right? I'll give it a shot!" Even the usual boundaries that seem to coalesce around reading as a gendered space in book clubs appear marginal to $H A M$. Since much of the literature involved in book club research focuses on the impact of gender relations in circumstances of social reading (for example, men's general lack of interest in reading groups, and men's purported discomfort with open ended discussions) (Long, 2003, 225; 146-7), it seems surprising that questions of sex/gender scarcely figure in how the members of $H A M$ self identify as readers. Although there are four female readers, and one male in $H A M$, it is not a space from which men "run away", states Karen. She feels that the impact of gender figures only "in passing, if it has direct relevance to the story, or the play, or whatever we're reading, but not in any formal way". For Karen, the general lack of focus on gender in $H A M$ speaks to the more existential concerns of the group, and how the fundamental concerns of living, dying, and staying healthy are generally construed as universal concerns:

We all have bodies, and we all are interested in health care as it pertains to us. So those issues, while they're gendered insofar as men and women have different health issues, I think that the genders equally share an interest in health issues globally. So, I don't think $H A M$ excludes anybody. I think it's very inclusive as a result of that.

\section{b) Reading as Tidalectic}

In $H A M$, reading assumes an affair of tidal proportions, a perpetual process of conveying the breadth of meaning from one location to another. Alan relates:

[I]f I try and recall my questions over time, I probably try to bring it back to the notion of how this work might relate to medical practice...to becoming more empathic, as a medical student or physician. 
Alan here suggests a form of reclamation in the movements of meaning, as a way to transport ideas from one shoreline to another, as if he is searching for the route of something (a method, a story, an anecdote) that begins in medical practice, is refracted through the lens of literature, and then gravitates back to the field of medicine. Gail similarly describes her readings in $H A M$ as a "tying together" of experiences: a knotting that makes use of frayed ends, "extrapolating on what we've read into our own lives, and putting that back". She expects to be moved by $H A M$, and comes to discussions asking: "What can we take from this, that: a) either we recognize, or b) we could hope to recognize in the future, to remember, use and think about?" Though Cathy finds that the members of $H A M$ generally agree on the most salient points, "conversing at a pretty common level of understanding", when this is not the case, rather than the conversation breaking down into a forced acquiescence, it instead widens itself to incorporate degrees of otherness. As Cathy points out, this movement, which is always becoming, constitutes the representational spaces of reading as grappling with the intrinsic variability of truth claims and subjectivity in general:

We share the different perspectives, and that's where it's really good... If we have different students at different stages of their medical careers, or ones who have graduated...they have different perspectives as well, because they may be...paediatricians...or orthopaedic surgeons, and as the readings are medically oriented, they can come at it slightly differently.

In the following example of discussing Allende's Paula, the readers move back and forth between the two common rooms of their disciplinary experience:

Alan: No matter how you disagree with it as literature, is this a way to communicate as a mother, a parent, to an offspring, just to let something go, and start talking? Isn't there a clinical observation that people in comas can hear?

Karen: People in comas...

A: ...can hear, in other words, if you keep talking, somehow the message gets through in some way...

$\mathrm{K}$ : It's like the question, do babies feel pain? You think they do, but how do you absolutely...

A: But...if you had a choice, as a parent or a loved one, sitting in the hospital, waiting for the specialist to rush by, or you said, look, go in there and just talk your life story. What the hell would someone do? Is there some clinical application to this?

Dara: I wouldn't suggest that they read this book, but... (Laughter)

To practice reading as an act of listening, which is never passive, becomes a way to allow a dialogue with otherness into the heart of one's own reflective capacities, an alwaysunresolved dialogic mode provoked by conversation. Approaching $H A M$ 's gravitational forces as "a counter balance to the biomedical model", Alan refers to HAM's monthly encroachments as a generative forum for his classroom praxis. In this way he deploys 
"some of the impulses of book clubs with the readings" into other coastlines of his life, including pedagogy with students.

\section{c) Reading for Resistance}

As a self-described member of "the outcasts of medicine," Bridget expresses how, because of her artistic inclinations, she is generally more sensitive to the emotional needs of patients. She often mentions how the time she spends with $H A M$ gives her much needed space for substantive resistance and survival within an academic environment from which she feels painfully alienated. Being able to speak of medicine in the manner that $H A M$ encourages "does help". Bridget uses her reading experience in HAM to express herself without disaffection, and to feel that, even as a medical practitioner, she is not estranged from her artistic nature.

\section{d) Reading for Aesthetics and Authenticity}

Not surprisingly, as someone "more on the $H$ side of $H A M$ than on the $M$ side," Dara approaches $H A M$ as a site in which to talk about literature generally and how it relates to her particular interests as a reader and writer. She believes that the partitioning of aesthetic interests between Medicine and Humanities is a false one:

I don't think you should overemphasize the divisions. There are members of this group who are quite sensitive to matters of aesthetics too... and to nuances of language. Every reader brings the sum of whatever they are to it.

Dara defines her "primary interest in reading as aesthetic," which involves looking at "how well the writer, through language, realizes whatever it is I think the writer is attempting to communicate, and how fresh it is, how vivid it is, how authentic it seems". In Dara's approach — which has rubbed off on $H A M$ as a whole - it is not enough for a reader simply to recognize that an author tackles monumental issues of living and dying, but to take it at least one step further, and look closely at how such tackling is actually enabled and invoked for readers through language. As Dara explains, even if an author's depiction consists of

... factual details, [and] stretches of description that are particularly compelling simply for their content, I might be saying, 'Well yes, but there's something profoundly falsifying about how this is rendered.'

There is also, in $H A M$, an immersion in a textual and topographical poetics of a different sort. It is important to note the group's repeated metaphorical use of water and place as descriptive vectors of their reading experience. For example, Bridget speaks of the geographical qualities of St. John's: “And it's the hills, and you always see Signal Hill, and you always see the ocean, and you smell it". Karen emphasizes the unguarded nature of people in Newfoundland, and regards such a trait as a general decontaminant; that "It's just in the water here", and that "There's a natural kind of interdisciplinariness about this place, because no one's really too excited about boundaries". Bridget refers to the geography of Newfoundland as something enveloping, and that it is "just totally pervasive in everything you deal with when you're on an island, and especially when you're from an island". Just as she carries an artistic sensibility that is so intrinsic it affects the very manner in which 
she approaches her role as a doctor, Bridget also speaks of an "island mentality, or an island sensibility", and that thinking from such a conceptual space, "just sets you apart, always".

There is a sense that, wherever her travels take her, Bridget's remnants of this life on an island persist metonymically, since they are "so unconscious, and so much a part of who you are," and though she recognizes the lasting impressions that living on an island has had on her life, she still asserts that it is a fundamentally unknowable force, and that, "I don't think anybody would be able to express, or recognize" what it actually consists of. In Bridget's recognition that "maybe literature and reading are more important in a place when you're trapped", and that in Newfoundland, "You can't leave if you want to, so you're stuck there at least for a little while", such a space as HAM functions to provide a reprieve from the alienating effects of isolation, whether geographically, or in regards to questions of authenticity in academic and professional circumstances.

\section{e) Preliminary Discussion of Case \#1}

For the readers in $H A M$, the experience of reading in the landwash performs as a mediating force in urban island experience. The four figurata we identify - the fracturing of boundaries that $H A M$ embodies and performs, the tidalectic or recursive to-and-fro movements that characterize their sound space, their use of communal reading to resist both homogeneity and self-preoccupation, and their attentiveness to aesthetics in reading experience - may be considered to be representational spaces (Lefebvre, 1991: 24). The lived experience of reading in $H A M$ is chaotic and subjectively articulated in very specific ways. So, even while the dominant, clinically driven, and official discourses of medicine can be seen to impinge on the everyday mental space of these readers, they actively and collectively symbolically appropriate representations (of life, death, medicine, and art) to talk back. Through smells and sounds of the quotidian-fish and chips and Quidi Vidi beer being delivered in Bitters-HAM shapes a genuine gathering place. There is room for both hunger and purpose here.

As in de Certeau's view of reading as an act of clandestine labour (1984), HAM's readers work at "poaching" and "appropriating" the materiality of reading back into the vectors of their own desires. Reading through the medical humanities becomes for group members an affirmation of the intrinsic promise of all reading experience, whether focusing in on a patient's chart or making sense of poetic verse. Through their readings, HAM's members dismantle representations that are common thoroughfare throughout the corridors of medical practice. What does it mean to be in a coma and not wake up? What does it mean to witness this experience in a child and then as a parent to write about it? How is a human body the world? Within the chop and surge of such non-hegemonic discourse reside struggle and regeneration, energy and strength.

Canadian curriculum theorist Cynthia Chambers (1999) recognizes that the only way we can approach the questioning of who we are is if we simultaneously seek to establish the corollary of where we are. The notion of the landwash, the space of perilous change between high and low tides, while representative of the ferocity of the Newfoundland shoreline, also configures as a material and metaphorical trope marking the shifting desires of HAM's readers. They repeatedly self-identify as being in-between, making sense of 
scientific claims through the lens of artistic vision and vice versa. The fluidity of boundaries is an important characteristic of the landwash. The Atlantic Ocean, with its sounds, its smells, its birds and its mists, is impossible to ignore while walking the streets of St. John's, and becomes an essential component underlying the psychic fabric of the place. More than a prison, the water acts as a passage for a reading of the world, and of one's place in it. It functions as a channel for international trade, but also for the drifting of thoughts, comparable to the outermost depths of any passionate and truly involved reading. It's a conduit for a sense of confinement, while also for an incomparable freedom.

We circle back to these ideas in our conclusion. Now let us turn to our exploration of a second book club in St. John's where, once more - through lowly asides and seemingly unspectacular musings - book history gains access to what is generative yet often unsaid in the annals of literary study.

\section{Notes from the Margin: Case Study \#2}

Our second case examines the uses of collective book experience through the Granny Bates Book Club $(G B B C)$. We are here interested in how readers in diasporic communities use discourse (in this case, children's literature) to negotiate subjective positionings. Diasporic communities refer to collectivities that are marked by migrations, displacements, locations and the journeys that surround forced movements of people. Arguably, Newfoundlanders have experienced forms of diaspora for decades as the island has consistently witnessed waves of emigration to "mainland" Canada and "the Boston states" of the eastern US. The provocative space of book club readership marked by the comings and goings of diasporic islander identity begins in the cozy attic of the Granny Bates Book Store in St. John's, where an eclectic group of adult women gather monthly to discuss their reading of children's literature. The women's pseudonyms are Sue, Melissa, Julie, Willow, and Hillary. In the winter of 2007, we join this interpretative community of children's literature enthusiasts, asking why adult readers choose to read children's literature, and how they use a book club to relate to aspects of childhood, how such readers use collective reading experience to relate to cultural struggles, and how gender is practiced within a book club in ways that help produce identities.

The $G B B C$ runs monthly meetings with five regular members, educated white women ages $28-58$ who variously self identify as writers, editors, librarians, mothers, and youth advocates. The club was instigated by "Sue" in 2005, who worked at Granny Bates Bookstore at the time. Participants include "come-from-aways" (individuals who have moved to NL to make it their home), and those who were born and bred in St. John's. Note that one member is originally from Newfoundland and has an Irish mother and a "Canadian" father. She feels she is not considered a true 'Newfoundlander' by some and confesses she "has a real beef about it." All members are drawn to the club by their vested interest in children's literature. The term 'children's literature' is used by the $G B B C$ members themselves to identify their chosen genre, which is young adult or juvenile fiction targeted at youth ranging in age from 12 to 18 years. Drawing our theoretical framework from the Saltwater Chronicles Research Study, we study how book club readers use language to constitute themselves as emplaced and gendered subjects. Geraldine McCaughrean's (2006) Peter Pan in Scarlet and Markus Zusak's (2006) The Book Thief constitute the two books read during our observer participation. Below we present the 
themes that emerged, whose four patterns illustrate the uses of the book club in members' daily lives.

\section{a) Legitimization: Closeted Lovers of Children's Fiction}

A sensitive issue with all of the readers is how, as lovers of children's fiction, $G B B C$ members have been teased throughout their adult careers. The $G B B C$ gives them a potential space to explore children's books in a manner unavailable in their everyday lives. Eyes actually light up when readers express the relief they feel to have found a group that not only shares their particular reading passion, but validates this interest in the face of hostile critics; that there are, in fact, like minded, educated women who share their "peculiar" literary tastes. Melissa confesses that she does not always admit to people that she enjoys reading children's books because of the negative reactions she has encountered. However, when she does confess her 'closeted' affinity for the genre, some 'come out' and disclose their love reading children's books and/or their interest to join the $G B B C$. An integral use of the club, articulated by the members very proud to belong to it, is a validation of their vested interest in a genre often shunned by other adults. As Willow puts it, "This book club gives people the right to not only read kids' books, but then to say I am reading this for a book club. So, back off! [laugh]."

Members cherish the fantastical element found in children's books: adventures of seeking treasure, discovering new worlds, or conquering new terrain. For Hillary, immersion in such fantasy spaces "is comforting. It's familiar, yet it's awakening and forces you to go back to a place or perspective that you may be have moved on from or chosen not to live by". Julie professes that, "adult fiction can be really hopeless, you know. It can be, I don't know, more demoralizing. Usually in young adult fiction, you're looking for a redeeming ray of hope at the end or something that doesn't leave you an emotional mess". The $G B B C$ readers speak with insider knowledge to remind us of how little room actually exists in adult life to indulge in the wide spectrum of forgotten possibilities of pretend worlds that reading children's fiction allows.

Inter-textual and comparative analyses dominate as reading practices in the $G B B C$, as each member elaborates how she relates to the book. As the club becomes a space where readers express how they 'feel' about a book, they use personal background knowledge to further discussion. During discussion of The Book Thief, within just a few sentences of transcribed dialogue, members fire off an explosive exchange of viewpoints and historical knowledge of Newfoundland history, $20^{\text {th }}$ Century politics, and even practices of genocide. Such talk demonstrates the women's use of local knowledge, as well as their excited, communal uses of building on the thoughts of others to learn.

\section{b) Aesthetic Evaluation and Display: Pleasure and Consternation}

Reading for the sheer enjoyment of children's books is a common confession of the readers. An author's evocative use of language and the readers' desire to "linger over it" is important for them in determining not only how well a book is written, but also signifying the beauty they get out of reading. In addition to the form and structure of a text, the literary power of language captivates them. While reflecting upon the significance of particular foreign words used in Peter Pan in Scarlet, one discussion ensues concerning 
what signifies a "real" word. The event is a porthole into these-and perhaps other Newfoundland readers' - uses of language as a weapon of cultural tradition, agitation, marking and distinction. Conflicting viewpoints around the word "janny" anchor the discussion:

Sue: Do you know that on line scrabble game I play with my daughter? Well, I tried to use the word Janny and they disallowed it. They said it wasn't a word.

Julie: You're kidding! Did you bring out your Newfoundland dictionary? [laughter]

Sue: Well, I did e-mail the server and said 'this is the thing'...[laugh]

Willow: And did you get a response?

Sue: No, not yet. But that is a great word.

The online Dictionary of Newfoundland English (1997) distinguishes janny as a noun, an "elaborately costumed person who participates in various group activities at Christmas; a fool, a mummer." Even though mummering, or jannying, is a Newfoundland Christmas tradition dating back over 200 years, the point is that janny was rejected as a real word when Sue attempted to use it in a medium that only recognizes words legitimized in an English dictionary. The incident becomes a rallying point for group members over the course of two meetings. Just like a real place feels it belongs where it is, so also does $a$ real word, like janny. Like the vernacular red clapboard building material of the little shop that encloses them, the word has grown here. It belongs.

\section{c) Identity Slippages: Regionalism, Nationhood, and Gender}

Further reflections on janny lead to speculations that the word might originate from a specific region in the Newfoundland. Hillary, who has lived outside the province for a number of years, admits she has never heard of the word. "Well, a lot of people say I'm not a real Newfoundlander," to which Julie states "I'm from here. I'm a third generation townie!" These are examples of the discursive binaries that post-colonial and feminist post-structural theorists point to as examples of how groups become "known" and juxtaposed to one another contextually, linguistically, and geopolitically as polarized dichotomies. The descriptor "Canadian" functions as a slippery identity marker for members of the $G B B C$, a finding also made by Fuller in her study of literary culture within Atlantic Canadian women. She writes:

How the nation is constructed and understood, and whether it is a notion that members of a particular community wish to retain or reject, depend on a community's standpoint, its position within ruling relations (Fuller, 2004: 13).

Arguably, the $G B B C$ serves as an ensemble of relations, which - in their movement, history, enunciation, and contestation-continually re-signify and transform the "fixed" and bifurcated identity of a Newfoundlander, not only as "townie" or "bayman", but as someone who resides outside of the "imagined community" (Anderson, 1983) of Canada itself. The women's prolonged focus on the meaning and efficacy of "janny" plays out their self-positioning as "island" readers. 
It is not only the vexed interplay between rural or urban, and mainlander or islander, that haunts the shifting ledgers of Newfoundland reader identity here. The women also use book club space to reterritorialize and deterritorialize notions around gender (Deleuze \& Guattari, 1987: 11). The members' reactions to representations of Wendy in Peter Pan in Scarlet, cast by the $G B B C$ as a "domestic slave", are of interest both for what is acknowledged and what is left silent. The group's characterization of Wendy's role as a submissive female and surrogate mother, shadowed by the strengths of Pan and Hook, displays a collective resistance to dominant sex/gender depictions commonly found in children's classics. The women worry about the stereotypical representation, taking seriously their roles as literary stewards within the public realm. However, even though Wendy appears to be stereotyped as a "domestic slave", Julie proposes an oppositional reading in which aspects of Wendy's strength emerge: "You get this sense that they looked up to her". In this reading, Wendy possesses maturity and leadership, helping to guide the crew of explorers. This quality, felt by all the readers, implies that indeed, Wendy does possess a backbone. In such a multi-dimensional discussion, the book becomes a piece in the movement of culture, and the "surplus value of the code" of gender gets decentred and modified by the readers (Deleuze \& Guattari, 1987: 10-11, 17, 21). The group's use of the book as a springboard for engaging social issues around gender shows them making a place for themselves out of preconceived notions and personal experience, a pattern of behaviour well substantiated in gender and literature studies (Fetterley, 1978; Radway, 1984; Westland, 1993; Sedo, 2002; Long, 2003), as well as spatiality literatures (Tuan, 1977; Mels, 2006; Robertson \& Radford, 2009; Robertson, 2010).

\section{d) Literacy Guides}

Members of the $G B B C$ admittedly read 'good' children's books "that feed your soul and enrich children" (Beale, 2006: n.p.), and have a clear and vested interest in their beloved genre. Many discussions centre on their disenchantment with how reading unfolds in schools today. As Hillary laments:

By the time you get to be older you know what, or have a better sense anyway, of what is a good book. What I really find hard to take in the schools is that [children] are just told to read, and it doesn't matter a damn what they read. They get no guidance and it's presented as if it is all equal and it isn't all equal, and if we don't say, like, 'I don't think this is good,' then how [are] they [going to] make those decisions?

Such interactions display the women's self-identifications as informed readers. Elizabeth Long (2003: 22) argues that book clubs create boundaries that separate readers from nonreaders, distinguishing participants as "socially cultured and literary people," thereby adding to social distinction and cultural capital. The concept of cultural currency is associated with Pierre Bourdieu (1984) and discussed by Chris Barker (2004: 37) "to be forms of accumulated knowledge, skills and advantages that a person has, giving a higher status in society which works in a system of exchange amongst social groups". The women use the book club space to expend cultural currency that might effect what children are reading, and to discuss their desires to influence institutionalized education, especially through their intimate relation to the province's most famous and vital exclusive independently owned children's book store, which has been operating for over 17 years. 
$G B B C$ readers take seriously their self-declared mandate to be informed so they can influence the reading practices of their own children, and more widely those throughout St. John's, and Newfoundland and Labrador. It must be noted that, until recently (sadly, Granny Bates Bookstore closed its doors as a commercial establishment at the end of September 2009), the institution had provided recommended reading lists for inquiring teachers and librarians, acting as a government sanctioned literary authority for the entire province. Granny Bates won the Best Specialty Book store in Canada in 2005, and the fact that it withstood for so long the incursion of larger Canadian and American multi-national chain competitors "is a statement in itself, in a market that is not huge that doesn't have a lot of discretionary dollars to throw around" (Beale, 2006: n.p.).

\section{e) Preliminary Discussion of Case \#2}

We identify four movements that mark the women's reading experiences: the use of the book club for validation and legitimacy against subjugating cultural norms; the use of $G B B C$ to establish taste and value standards around words and representations, some specifically anchored in Newfoundland English; the use of book reading and each other to flesh out dimensions of gendered and emplaced selfhood; and the use of communal reading experience to establish cultural agency as stewards over the lives of children. As a representational space for these urban island readers, these patterns play out generativity, social memory, and heterogeneous connectivity in the book club.

The women use their reading experiences within the $G B B C$ as a space of agency and aliveness. By working dialogically with each other and at the intersections of classic and contemporary tales, they find ways to claim authority. The $G B B C$ provides discursive conditions for women to grapple with embodied and emplaced aspects of their gendered and regional identities, including maternity, domesticity, speech patterns, and what readers hope for their own children. Arguably, such "disobedient" moments allow them to inhabit their desires more fiercely, by decentring symbolic monoliths and opening up the game of identity politics. In so doing, the women create spaces not only to make a future for themselves, but - given their devotion to childhood and the disjunctive temporalities that govern any reading experience - for future generations of Newfoundlanders.

Arguably, the very ground of their literary encounters and migrations-The Granny Bates Book Store - constitutes an important "third space" for the readers (Bhabha in Rutherford, 1990: 211). The book store is itself an "object" that facilitates hybridity within. Bhabha argues that cultural space gets mediated through the process of identifying with and through other objects. The reader herself is always ambivalent, and the use of cultural objects to think through allows for moments of dissembling and migration. The Granny Bates Bookstore was (and remains in social memory) an icon within the province. Both children's literature and niche book stores specializing in children's literature are typically designated within the public domain as feminine spaces vulnerable to political and economic domination. Even so, Granny Bates managed to survive, and even thrive, throughout difficult times. It did so through a curious mix of innovation, old-fashioned spirit, nationalism, technological savvy, inspired buying habits, indefatigable energy and generosity (the owner made on-site visits to remote schools and libraries throughout the province to encourage and disseminate new titles). A mix of counter cultural and multicultural books for youth, and a niche customer base flung far and wide, facilitated Granny 
Bates Bookstore's survival even when foot traffic was light up the hill. Granny Bates was a venerable institution within St. John's, and arguably, to be associated with it (with her!) through the venue of the $G B B C$ also marks readers as different, non-assimilationist. The third space of the book store enables a representational space within its readers that is generative, haunted by desire, and rhizomatic in the multiple routes/roots of its literary reach.

The women's powerful collective identification as literacy guides gives their discussions an embedded function within this transformative third space, to position themselves as active agents, constantly articulating and deploying their cultural capital for resistant purposes, by appropriating children's books they 'see fit' to read, both for themselves, and for future generations of 'literate' Newfoundlanders. Even so, their meetings are marked by ghosts from the past. As psychoanalysis reminds us, childhood is never resolved, forgotten, or left behind. Instead, it exists as "something in which we continue to be implicated" (Rose, 1984: 12). Not only are the readers' voices overpopulated by the affects of wounds from the past (whether these take the distinctive form-well entrenched in the Newfoundland imaginary - of not being considered a "real" Newfoundlander because your dad was a "Canadian, or arguing over the authentic value of a Newfoundland word from the past); but such hauntings show the enfolding of time into space in book club culture. If it is true, as Chafe (2008: 28) suggests, that a sense of "perpetual belatedness" permeates all Newfoundland fiction, then arguably the $G B B C$ shows urban island inhabitants taking the bull by the horns. Together they confront and contest those losses (that circulate in language and the policing of who a "real" Newfoundlander really is) that they are no longer willing to digest. It is through the "anti-museum" (de Certeau, 1984: 108) of memory that these women collectively de-institutionalize taken-for-granted notions of both Newfoundland identity and children's fiction, using their readings to get back to private and forgotten hurts or joys of childhood that adult readers are expected to be rid of. For de Certeau (1984), memory is not recognizable. We remember our lives unconsciously, in fragments that function like the presence of absence in reading. Questions of the production, distribution and legitimization of knowledge here also arise, as Newfoundland, despite its historical significance, remains a routinely ignored part of Canada, even ostracized from the grouping of 'Atlantic' provinces. Dismantling certain utterances like janny sheds light on how official knowledges become validated recursively, through time and language. Arguably, the time spent in the book club discussing words like janny speaks to the rich breeding ground that Newfoundland English constitutes as a site of local marking, historical memory, and possibility.

\section{Island Studies}

Our Saltwater Chronicles occur in the aftermath of the destruction of the fisheries habitats that have, in recent centuries, provided the primary source of livelihood and identity for Newfoundlanders and their families. It is a cruel destruction fuelled by devastating mismanagement by federal and provincial authorities. The non-selective fishing by large draggers continues on the Grand Banks today. While it would be misleading to say that the cod moratorium constituted a topic of focus for either of the two book club communities we observed, arguably the readers' common sense of struggle, outreach, and community can be read against this backdrop. Fallout from the fisheries collapse gave rise to a 
systemic crisis that is still very much a part of daily life and news for ordinary Newfoundlanders, who- on the radio talk shows and in the newspapers, in hospital waiting rooms and in book stores - worry about when they will see their children and grandchildren again, and a viable economic future. For $H A M$ and $G B B C$ readers, reading and the talk it engenders, function as fiercely material things which, even in a spirit of play, can serve as effective conduits of hope. So, whether it is the status of the humanities in medicine, or the fate of children's literature in contemporary culture, St. John's readers argue that things can be better, and they use book club space collectively to function as a think tank for creating more humane social relations. This quality-let's call it a disposition of generosity toward the other, characterized by intellectual and aesthetic openness in reading - has been identified by some island researchers (Glissant, 1989) as a movement toward collective voice and survival in the aftermath of colonization. We would suggest that, for our readers, the book club acts as a temporary haven in an urban coastal community still feeling the aftershocks of the sea's destruction.

At these cross-currents, then, the participants of our Saltwater Chronicles use reading together to learn anew. Reading on 'the Rock' is a place for argumentation parlayed into civic rituals underwritten by feelings of hope and responsibility to current and succeeding generations of Newfoundlanders. HAM readers maintain a website that functions as a living archive, a material/metaphorical way to register and migrate poetically through the displacements and dislocation of "reading like a doctor". Never far from the surface in $H A M$ and $G B B C$ is the memory of times when Newfoundlanders' language and culture were suppressed. The readers write a book of the future through their work together, perhaps re-viewing the melodrama of the past (hardship and endurance) to examine those fissures, ambiguities, and obscurities of meaning that can function as spaces of hope.

In a study of contemporary Newfoundland literary fiction written by Newfoundland authors, Paul Chafe (2008: iii) distinguishes a common thematic thread: character development in Newfoundland fiction always enfolds into a relationship with place. While these intersections between place and character, Chafe argues, are variously depicted and always troubled, some Newfoundland writers (Kenneth Harvey, Lisa Moore) use the city of St. John's as a story board on which to conjure a new vision of Newfoundland identity. What is remarkable here is that St. John's itself is distinguished as a liminal space. In its association with isolation, the modern city configures a "condition of enislement that is not the sole property of Newfoundland outporters" (Chafe, 2008: 233). The figure who emerges in here is marked by "self-reflexivity" as a "unifying Newfoundland trait" (ibid.: 25). S/he "blurs the line between work and play"... "at work when he is not working" (ibid.: 253). Elusiveness, contradiction, deferral, and a compulsive need to take to the streets or to the pubs to observe and think characterizes this Newfoundlander (ibid.). S/he is a bourgeois scavenger of ideas, both an observer and an author of the present. In his compelling portrait of this "unhomely subject" who constantly revises and revisits questions of Newfoundland identity, Chafe gestures to the unfinished work of Walter Benjamin (The Arcades Project) (see Other Voices, 1997). Here the Flanêur emerges as the perfect $20^{\text {th }}$ Century hero, a "foil and conscience" (ibid.: 263) to post-modernity and island identity. For Chafe, the figure of the Flanêur is the consummate condensation of contemporary urban identity on the island of Newfoundland. 
We would like to leave our Island Studies readers with a tantalizing thought. Perhaps the book club members configured throughout our Saltwater Chronicles are Flanêurs, whose capacity to catch things in flight through the Flanêuries of reading is what emplaces them as urban island readers in Newfoundland. Neither "bayman or "townie" (in the usual sense), these readers do not always feel at home with where they are, but are perhaps more so in the interstitial landwash spaces of their beloved book clubs.

Denis Cosgrove, (not a Newfoundlander, but born and bred on an island) writes of the jarring experience he had as a child, landing for the first time on the mainland: "the disappearance of any boundary...brought home an existential significance that I had never before experienced viscerally" (Cosgrove, 2007: 15). Newfoundland communities-like other archipelagic groups whose roots and routes populate the periphery-historically have looked to the outside for access and mobility. The sea is a boundary. Even so, it pushes back at the notion of limits with all of the intensity of a wild and living thing. Our work demonstrates the speculative energy and imagination of such archipelagic perspectiveswilling as they are through the commonplace byways of friends coming together to read at a pub called Bitters or a children's book store on Bates Hill - to challenge traditional boundaries, be they disciplinary, semantic, historical, or between academic disciplines in the humanities and medical sciences. The condition of constitutive inter-relatedness and its informing effects on members of island archipelagos is essential to the notion of archipelagic identity, as well as to notions of literary culture and representational space (Schwzyer \& Mealor, 2004). The readers of our Saltwater Chronicles keep at a tangent, making the circle wide and swimming out on their own, thereby filling the element with signatures of their own frequency. In the dark of the sea, they shine bright.

\section{Acknowledgements}

Saltwater Chronicles: Reading the Regional Book Club of Newfoundland and Labrador was funded by the Social Sciences and Humanities Research Council of Canada, 20032007, Grant Number 040121303, Judith P. Robertson, Principal Investigator, with David Lewkowich and Jennifer Rottmann emerging as co-researchers in the course of the project. A Canada Graduate Scholarship from SSHRC, Grant Number 76620070764 was awarded to David Lewkowich, resulting in his MA Thesis (Lewkowich, 2008a). A University of Ottawa Faculty of Education Excellence in Research Scholarship supported Jennifer Rottmann's involvement, resulting in her MA Thesis (Rottmann, 2008). The University of Ottawa Ethics Research Board (File Number 010406) approved the study for active research to December, 2007. We also thank the anonymous readers of this paper for pushing us to extend our analyses, and for providing invaluable leads that we would otherwise have missed. Thanks to the Centre for Newfoundland Studies for helping us to track down historical documents pertaining to book history in St. John's. And to the uncommon readers of the book clubs themselves-especially to individuals in the Humanities, Arts and Medicine Interest Group and the Granny Bates Book Club, who welcomed us into the intimacies of their readings - our heartfelt thanks. 


\section{References}

Allende, I. (1996) Paula, New York, Harper Perennial.

Anderson, B. (1983) Imagined Communities: Reflections on the Origin and Spread of Nationalism, London, Verso.

Bachelard, G. (1964) The Poetics of Space, translated by M. Jolas, Paris, Orion Press.

Baldacchino, G. (2008) 'Studying Islands: On whose terms? Some Epistemological and Methodological Challenges to the Pursuit of Island Studies', Island Studies Journal, Vol. 3, No. 1, pp. 37-56.

Barker, C. (2004) The Sage Dictionary of Cultural Studies, London, Sage.

Barker, W. \& Hannaford, S. (2009) 'Towards a History of the Book in Newfoundland' in History of the Book in Canada, www.hbic.library.utoronto.ca/fconfnfld en.htm.

Beale, N. (Interviewer) (2006) The Biblio File: Interview with Margie Macmillan http://cdn4.libsyn.com/nigelbeale/Margie_Macmillan_Granny_Bates_Books_Newf July06 .mp3.

Beer, G. (2003) 'Island Bounds' in R. Edmond \& V. Smith (eds.) Islands in History and Representation, London, Routledge, pp. 32-42.

Bhabba, H.K. (1996) 'Culture's In-Between' in S. Hall \& P. du Gay (eds.) Cultural Identity, London, Sage, pp. 53-60.

Bourdieu, P. (1984) Distinction: A Social Critique of the Judgment of Taste, Cambridge MA, Harvard University Press.

Brady, I. (2000) 'Anthropological Poetics' in Handbook of Qualitative Research, $2^{\text {nd }}$ Ed., N. Denzin \& Y. Lincoln (eds.) Thousand Oaks CA, Sage, pp. 949-979.

Braithwaite, E.K. (1983) 'Caribbean Culture: Two Paradigms' in J. Martini (ed.) Missile and Capsule, Bremen, Universitat Bremen, pp. 9-54.

Callanan, M. (2007) 'Editorial', Riddle Fence, Vol. 1, pp. 1-4.

Chafe, P. (2007) 'When a Man Is an Island: Contemporary Newfoundland Literature and Identity’, Riddle Fence, Vol. 1, pp. 37-40.

Chafe, P. (2008) 'Only an Artist Can Measure Up to such a Place': Place and Identity in Contemporary Newfoundland Fiction, unpublished doctoral thesis, St. John's NL, Memorial University of Newfoundland.

Chambers, C. (1999) 'A Topography for Canadian Curriculum Theory', Canadian Journal of Education, Vol. 24, No. 2, pp. 137-150.

Cosgrove, D. (2007) 'Island Passages' in G. Baldacchino (ed.) Bridging Islands: The Impacts of Fixed Links, Charlottetown, Acorn Press, pp. 15-28.

Darnton, R. (1982) 'What is the History of Books Revisited', Modern Intellectual History, Vol. 4, No. 3, pp. 495-508.

De Certeau, M. (1984) The Practice of Everyday Life, translated by S.F. Rendall, Berkeley CA, University of California Press, 1984. 
Delisle, J. (2008) 'A Newfoundland Diaspora? Moving through Ethnicity and Whiteness', Canadian Literature, Vol. 196, No. 1, pp. 64-82.

DeLoughrey, E. (2007) Routes and Roots: Navigating Caribbean and Pacific Island Literature, Honolulu HI, University of Hawai'i Press.

DeLoughrey, E. (2000) 'Literatures of the Archipelagoes: Caribbean and Pacific', www.hawaii.edu/cpis/psi/pdf/LitOfArchipel2000.pdf.

Deleuze, G. \& Guattari, F. (1987) A Thousand Plateaus: Capitalism and Schizophrenia, Minnesota MN, University of Minnesota Press.

Devereux, E.J. (1963) 'Early Printing in Newfoundland', Dalhousie Review, Vol. 43, No. 1, pp. 57-66.

Doran, B. (Director). (2005) Hard Rock and Water, St John's NL, Morag Productions, in association with CBC Newsworld.

Ellis, C. (2004) The Ethnographic I: A Methodological Novel about Autoethnography, Walnut Creek CA, Altamira Press.

Fetterley, J. (1978) The Resisting Reader: A Feminist Approach to American Fiction, Bloomington IN, Indiana University Press.

Fowler, K.J. (2004) The Jane Austen Book Club, New York, Putnam.

Fuller, D. (2004) Writing the Everyday: Women's Textual Communities in Atlantic Canada, Montreal and Kingston, Canada, McGill-Queen's University Press.

Hiller, H. (1999) 'City Lives and City Forms: Critical Research and Canadian Urbanism', The Canadian Review of Sociology and Anthropology, Vol. 36, No. 2, pp. 290-312.

Huntley, P. (2003) The Hemingway Book Club of Kosovo, New York, Penguin.

Glissant, E. (1989) Caribbean Discourse: Selected Essays, Charlottesville VT, University Press of Virginia.

Kaufman, R. (2004) 'That, my dear, is called reading': Oprah's Book Club and the Construction of a Readership' in P. Schweickart \& E. Flynn (eds.) Reading Sites: Social Difference and Reader Response, New York, Modern Language Association of America, pp. 221-255.

Laity, P. (ed.) (2001) Left Book Club Anthology, London, Victor Gollancz.

Lefebvre, H. (1991) The Production of Space, Cambridge MA, Blackwell.

Lewkowich, D. (2008a) Poaching in the Landwash: An Interrogation of Cultural Meaning in a Reading Group from St. John's, Newfoundland, unpublished master's thesis, Ottawa, Canada, University of Ottawa.

Lewkowich, D. (2008b) Poaching in the Landwash: Reading in the Folds of Place (film), www.saltwaterchronicles.org/.

Long, E. (2003) Book Clubs: Women and the Uses of Reading in Everyday Life, Chicago IL, University of Chicago Press. 
Marshall, I. (1998) Storyline: Exploring the Literature of the Appalachian Trail, Charlottesville VT, University Press of Virginia.

Mels, T. (2004) Reanimating Places: A Geography of Rhythms, Burlington VT, Ashgate.

McCaughrean, G. (2006) Peter Pan in Scarlet, Oxford, Oxford University Press.

Manguel, A. (1998) A History of Reading, Toronto, Knopf Canada.

Morris, E. (n.d.) 'Library Notes.' Annual Reports on Library and Atheneum Club activity in St. John's: 1809-1892, Shortis, Vol. 1, 44 pp.

Nafisi, A. (2003) Reading Lolita in Tehran: A Memoir in Books, New York, Random House.

Other Voices (1997) Walter Benjamin's The Arcade's Project, March, www.othervoices.org/gpeaker/Flaneur.html.

Overton, J. (1988) 'A Newfoundland Culture?' Journal of Canadian Studies, Vol. 12, No. $1-2$, pp. 5-22.

Radway, J. (1997) A Feeling for Books: The Book-of-the-Month Club, Literary Taste, and Middle-Class Desire, Chapel Hill NC, University of North Carolina Press.

Robertson, J.P. \& Radford, L. (2009) 'The Private Uses of Quiet Grandeur: A Study of the Literary Pilgrim', Changing English: An International Journal of English Teaching, Vol. 16, No. 2, pp. 203-209.

Robertson, J.P. (May 2010) 'Poems in Newfoundland Time', Academic Matters: OCUFA's Journal of Higher Education. www.academicmatters.ca/.

Rottmann, J. (2008) Notes from the Margin: Understanding the Collective Reading Experience in St. John's, Newfoundland, unpublished masters thesis, Ottawa, Canada, University of Ottawa.

Rose, J. (1984) The Case of Peter Pan: Or the Impossibility of Children's Fiction, Basingstoke, Macmillan.

Rutherford, J. (1990) 'The Third Space: Interview with Homi Bhabha' in J. Rutherford (ed.) Identity: Community, Culture, Difference, London, Lawrence \& Wishart, pp. 207221.

Sanders, S.R. (1996) 'The Geography of Somewhere', Presented to Civic Tourism Conference, March 16, Prescott, Arizona, www.civictourism.org/documents/SandersTalk_001.pdf.

Sanders, S.R. (1997) Writing from the Centre, Bloomington IN, Indiana University Press.

Schwyzer, P. \& Mealor, S. (2004) Archipelagic Identities: Literature and Identity in the Atlantic Archipelago, 1550-1800, Burlington VT, Ashgate.

Sedo, D.R. (2002) Badges of Wisdom, Spaces for Being: A Social History of Women's Reading Groups, Ph.D. Dissertation, Vancouver BC, University of British Columbia.

Shaffer, M.A. \& Barrows, A. (2009) The Guernsey Literary and Potato Peel Pie Society, New York, Random House. 
Simpson, A. (2007) Quick, Toronto ON, McClelland \& Stewart.

Tuan, Yi-Fu (1977) Space and Place: The Perspective of Experience, Minneapolis MN, University of Minnesota Press.

Walsh, D. \& Jones, M. (2007) 'Finding the Links: Structure and Agency on Twillingate and Fogo Islands' in G. Baldacchino (ed.) Bridging Islands: The Impact of Fixed Links, Charlottetown, Acorn Press, pp. 85-103.

Welty, E. (1941/2002) On Writing, New York, The Modern Library.

Westland, E. (1993) 'Cinderella in the Classroom: Children's Responses to Gender Roles in Fairy-tales', Gender and Education, Vol. 5, No. 33, pp. 237-249.

Zusack, M. (2006) The Book Thief, New York, Alfred A. Knopf. 